OOLL

696

P2618F28

1911

BIRDS

ce

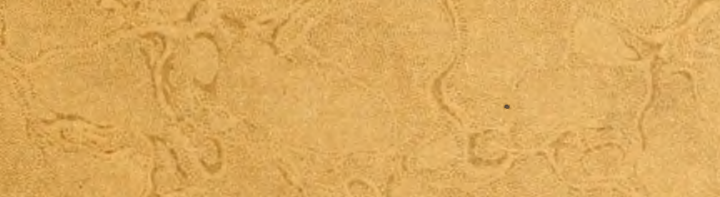

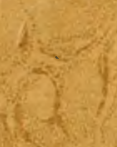

4

$\sqrt{2}+x^{2}$

retion in

(3)

1.

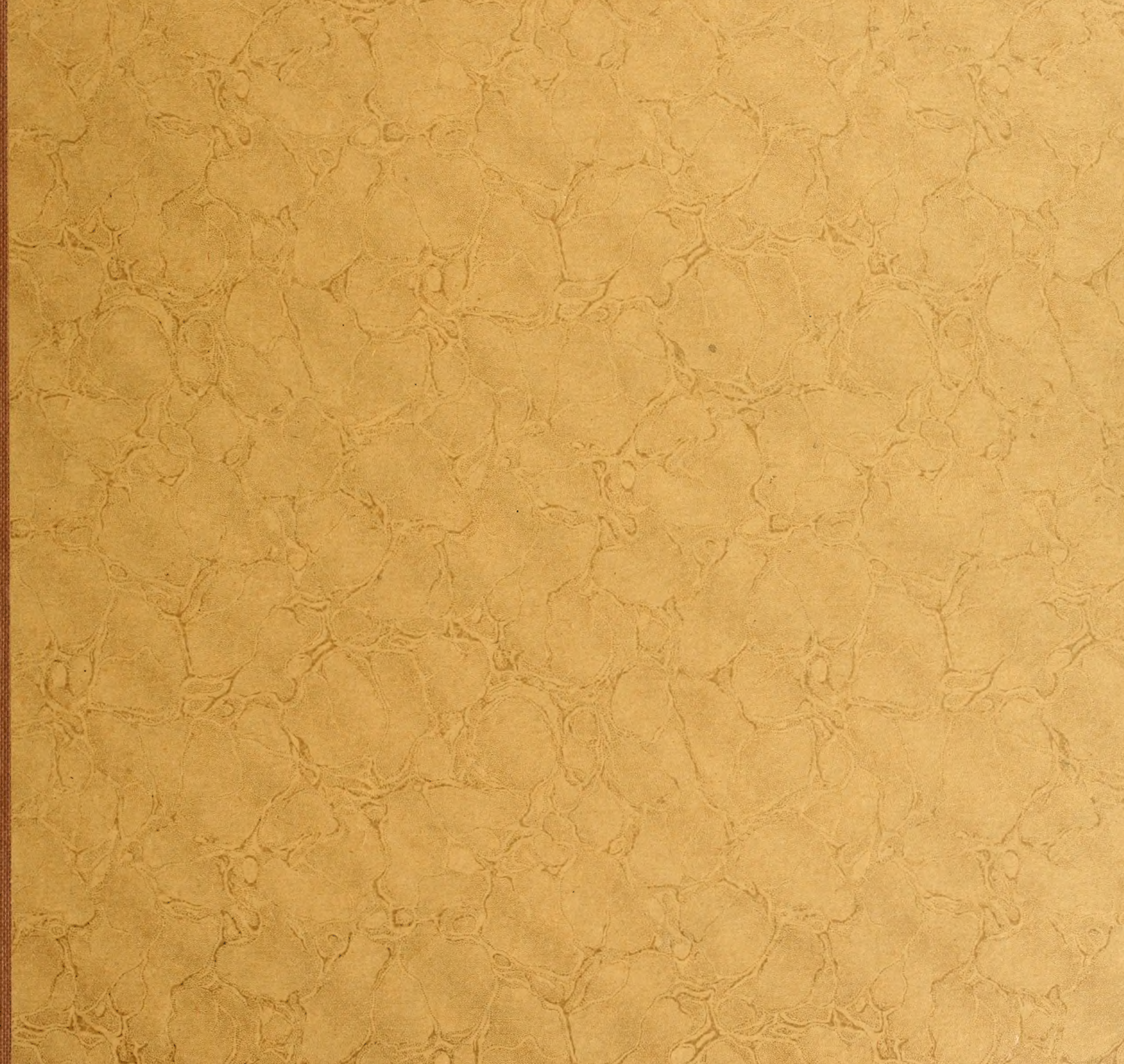



IDemoirs of the Museum of Comparative $\mathbb{Z}$ oölogy

AT HARVARD COLLEGE.

Vol. XL. No. 2.

\section{BREWSTER'S WARBLER.}

BY

WALTER FAXON.

With ONe Plate.

CAMBRIDGE, U. S. A.:

IDrinted for the SiDuseum.

JANUARY, 1911. 

SDemoirs of the IDuseum of Comparative $\mathbb{Z}$ oölogy AT HARVARD COLLEGE.

Vol. XL. No. 2.

BREWSTER'S WARBLER.

BY

WALTER FAXON.

With One Plate.

CAMBRIDGE, U. S. A.:

Trinted for the SDuseum.

JANUARY, 1911. 


\section{BREWSTER'S WARBLER.}

Three years ago, in the Auk for October, 1907, I published an account of a male Brewster's Warbler found during the month of June on the edge of a swamp in the town of Lexington, Mass. Although the bird remained in the same locality throughout the breeding season, neither his mate nor nest was discovered and little hope was entertained that this interesting addition to the Lexingtonian fauna would become firmly established. That such is the case, however, the observations recorded in these pages will tend to show. While I was walking through this same swamp with Dr. W. M. Tyler on the fifth of June of this year (1910), my companion detected a Brewster's Warbler, apparently a female, in some shrubbery in one corner of the swamp, within one hundred and seventy yards of the station occupied by the bird which I discovered in 1907. Close at hand, on the other side of a fence that divides the swamp from a jungle of Gray Birches and Raspberry vines, a male Brewster's Warbler and a male Golden-winged Warbler were chasing each other about amid the low trees and shrubs. Both were singing, one in quick response to the other. The song of each was the familiar song of the Golden-wing, although a difference between the voices of the two birds was discernible, the quality of the tone being sharper and clearer in the Brewster's than in the Golden-wing. The difference however was no greater nor of any other sort than what one perceives in comparing the songs of different individuals of the Golden-wing. In the mutual chase of the two males, the Golden-wing seemed to be the more aggressive.

On returning to the spot where we had left the female, we flushed her from her nest which rested firmly on the ground at the foot of some stalks of Meadow Rue and Rugose Goldenrod, and contained five eggs — white speckled with black or dark brown around the larger pole, and indistinguishable from the eggs of the Golden-wing. The nest, too, was fashioned like the Golden-wing's, being built of dry leaves and Grapevine bark, lined with fibrous shreds of plants and with 
White Pine needles. The outside diameter of the nest was $4 \frac{1}{2}$ inches, the inside diameter $2 \frac{1}{2}$ inches, height 4 inches, inside depth $2 \frac{1}{2}$ inches. ${ }^{1}$

The male Brewster's Warbler was one of the pure type, with clear gray back, brilliant yellow crown and wing-patches, and silk-white under parts without any trace of yellow. The female displayed the normal plumage of the female Brewster's, differing from the male in having the back and hinder part of the crown lightly veiled with olive, the wing-patch paler yellow and distinctly divided into two parts, and the breast lightly suffused with yellow, leaving the chin and throat clearly white.

The male Golden-wing that was associated with these Brewster's Warblers was a bird of extraordinary brilliancy and purity of plumage, the white color of the lower breast and belly being less obscured by ash than is the case in many examples, throwing into strong relief the pure black of the throat, the yellow of the wing-coverts and crown and the exquisite blue-gray of the back. The black of the throat extended clear up to the base of the bill, indicating a bird that had attained at least to the second nuptial plumage, if we accept Dr. Dwight's diagnosis.

Two other places on the border of this prolific little swamp were occupied as singing stations by two male Golden-wings, from the time of their arrival on the fifteenth of May. The nest of neither of these was found, nor for that matter were their mates seen until, in the latter part of June, they led their young forth from the nest to feed in the Maple Swamp. From that time onward both of these males, with their mates and young, together with the proprietors of the nest discovered on the fifth of June and their young, were followed up to the time when the family ties were dissolved and the young had acquired the full first-autumn plumage, about the twentieth of July.

The stage upon which the little domestic scenes now to be described were enacted was formed for the most part by the Maple Swamp, a moist area of about 15 acres, grown up chiefly to Red Maples, with a sprinkling of Elms, Red Oaks, and White Pines. The ground beneath, always damp and screened from the parching rays of the sun, is clothed with a rank growth of Cinnamon Fern four to six feet high, interspersed with Spinulose, Boott's, Crested, and Lady Fern, while ample tracts are given over to thickets of Raspberry vines, well-nigh impenetrable. Patches of Jewelweed claim a share of the spongy soil, - spots dear to the Connecticut Warblers in the autumn. Here and there one sees the delicious green of the Clintonia and in a few favored places the eye 
fatigued in the pursuit of the elusive little Warblers rests with a sense of relief upon the exquisite tracery of Purdie's Fern. ${ }^{1}$

As July advances, tall stalks of Meadow Rue lift their white plumes to a height of six to ten feet above the ground, while beneath them Canada Lilies swing their golden bells and ring out, to the spirit, "ditties of no tone."

- Abutting on one side of the swamp is a tract of long-abandoned tillage land now appropriated by young Gray Birches, with one or two Red Oaks of a much older and larger growth. The areas between the trees form a veritable jungle of Raspberry vines and Poison Dogwood. On another side the swamp is bounded by a grove of Birch with a more recent undergrowth of Raspberry. On the third side one passes by an abrupt transition into an open meadow, the haunt of Meadowlarks and Bobolinks, while the limit of the swamp on the fourth side is fixed by the edge of a woodland of upland Oak cleared of every vestige of undergrowth - the kind of woodland beloved of man but abhorred by most kinds of birds.

To return to the Brewster's Warbler and nest: the sixth and seventh of June were rainy days and the female bird sat so close that I could peer into the nest with my face within a few feet of her without her once abandoning her charge. The male Brewster's spent most of the time singing in a Red Oak in the Birch jungle within forty-five yards of the nest, while the male Golden-wing was never heard to sing from this time onward.

On the morning of the eighth there were five little naked newly-hatched birds in the nest.

On the ninth Messrs. William Brewster and H. A. Purdie accompanied me when I visited the nest, and on that day we got the first inkling of the marital relations of the birds under observation: the male Golden-wing was seen feeding the female Brewster's Warbler in the shrubbery near the nest. After this day he was constant in supplying food to the female or the young, while the male Brewster's spent most of the time singing in his favorite tree and was never seen to feed anything but himself. He would, it is true, make occasional visits to the immediate neighborhood of the nest, particularly if any commotion was excited there by the presence of a squirrel or other unwelcome intruder. On such occasions he showed as much concern as if he had a personal interest in the nest; but every field observer will recognize that this alone is no evidence of proprietorship in the nest. It is a matter of every day observation that birds

${ }^{1}$ Aspidium concordianum, a delicate, finely-cut form of A. spinulosum, discovered by $\mathrm{Mr}$. H. A. Purdie in the neighboring town of Concord. 
of all kinds, even of the most remote relationship, will evince this sympathy with their neighbors in affliction. As an instance to the point: one day in this very place Dr. Tyler caught a young fledgling Veery in his hat: in an instant the cries of the young bird gathered around us every feathered inhabitant of the swamp.

On two occasions the male Brewster's Warbler, in the absence of the male Golden-wing, was seen to engage in what seemed to us a vicious pursuit of the female, only to meet with a repulse.

When highly excited by the intrusion of a squirrel or any other marauder, both sexes of the Helminthophilae, ${ }^{1}$ but more especially the female, emit a series of peculiar scolding burry notes which suggest the song of the Short-billed Marsh Wren.

By the fourteenth of June the scanty clothing of the nestlings in the shape of scattered patches of gray down was reinforced by the incipient feathers of the so-called first or juvenile plumage. These (on the back) were of an obscure olive-gray, but on the wings the future transverse bars of the median and greater wing-coverts were apparent as yellowish pin feathers. The throats were still bare, the skin thereof being of a reddish-brown hue. On the following day (June 15) the feathers of the throat were just visible, of an olive- or yellowish-gray color.

On the morning of the seventeenth of June the young were all out of the nest, clinging to the low shrubs and Cinnamon Ferns near the nest, a foot or two above the ground. They are now olive-colored on the crown, olivaceous gray on the back; the wings are marked by two transverse widely separated yellowish bars; the under parts are ash-colored tinged with yellow; there are no throat or cheek patches, or clear traces of a trans-ocular streak; the tail feathers, just beginning to sprout, are olive-gray, or olive-slate, like the primary quills of the wings. In appearance and habit they were grotesque little fellows,

${ }^{1}$ Mr. Oberholser (Smithsonian Mise. Coll., Quarterly Issue, May 13, 1905, 48, p. 66) holds that the name Vermivora must supplant Helminthophila Ridgway (1882). The genus Vermivora was established by Swainson in an essay published in the Zoological Journal, April-July, 1827, 3, p. 170. The genus was there diagnosed and its type species, Sylvia vermivora, explicitly designated as well as implied by tautonomy. In a later-written paper (Philos. Mag., June, 1827, 1, p. 434), dealing exclusively with a collection of birds discovered in Mexico by the Bullocks, Swainson assigned Sylvia solitaria Wils. $(=S$. pinus Linn.), which he thought to be congeneric with S. vermivora, to the genus Vermivora, referring back to his earlier paper in the Zoological Journal for the foundation of the genus. In the later-written paper $S$. pinus appears as the only species in the genus Vermivora merely because it was the only species of the group represented in the Bullock collection.

Swainson's second paper seems to have been published by chance before the first paper, and therefore Mr. Oberholser maintains that $S$. pinus must be taken as the type of the genus Vermivora. Thus is plain fact perverted and the careful work of an ornithologist defeated in order to save the countenance of an absurd priority rule-of-thumb. If the genus Vermivora be accepted with Mr. Oberholser's connotation, it surely cannot be ascribed to Swainson, but rather to Swainson's editors! If Codes of Nomenclature make no provision for a peculiar case like this, so much the worse for the Codes. 
clinging with their disproportionately long legs to the low herbage, like peeping Hylas in the springtime elinging to the grasses and weeds above the surface of the water. The little thread-like natal plumes still waving from the tips of their crown feathers enhanced the oddity of their appearance. Up to this time they were absolutely silent.

By the twentieth of June the young birds had become more active and volatile and had retired by short flights into the swamp to a distance of some forty yards from the nest. Their plumage is now firmer and more compact, the tail feathers about one quarter of an inch in length, the color's essentially the same as described on the seventeenth. 'Their whereabouts is now often revealed by their peculiar little call for food - a chirp resembling in no remote degree the sound of black crickets.

On the twenty-fourth of June the tails of the fledglings had reached a length of about one inch and displayed conspicuously in flight the white portions of the inner webs of the three outer pairs of feathers. Up to this time the young birds lived exclusively among the Cinnamon Ferms and Raspberry vines, on the ground or within from two to four feet of it. They were exceedingly elusive creatures, making short flights from one dense cover to another. The whole family life was essentially terrestrial. The parent birds, $i$. e. the male chrysoptera and the female leucobronchialis, would now and then fly up into the trees for food (which consisted largely of a light green larva one half or three quarters of an inch long) but they would soon return to the young in the chief source of the food supply, the shrubbery below. Owing to the young birds' habit of self-concealment it was impossible to determine with precision how many members of this family escaped the perils of infancy, but I feel very sure that three, and probably four, grew to maturity.

Until now (June 24) the male leucobronchialis continued to sing, for the most part from his chosen station in the Birch jungle. If by chance the brood of young birds with their parents came into the edge of the jungle, or near it, he was very likely to be found near them; but if they moved into the deeper recesses of the swamp he never followed them, whereas the whole life of the male chrysoptera now consisted in supplying the young mouths with food. By June 30 the male leucobronchialis was undergoing his moult and had lost most of his tail feathers. On July 3 all the old feathers of the tail had been cast. On July 10 the growth of the new tail was well advanced, while the moult of the body feathers was still going on. After this he was seldom or never seen and the inference is inevitable that he passed the season without a mate. His pro- 
tracted period of song, early moult, and probable early migration would be the natural concomitants of celibacy.

On the 26th of June we found the second of the three male Golden-wings feeding a brood of young in the Birch wood on one side of the swamp. This male also, to our astonishment, had taken a Brewster's Warbler for a mate! He could be readily distinguished at a glance from the first one by his duller plumage, the white of the lower breast and belly being more heavily tinged with ash. The young birds of this family were distinctly younger than the other brood - by as much as three or four days, I should think. They were also more numerous - five or six, apparently - and revealed more differences in color than those that had been previously studied. The variations were especially obvious in the wing-bars which in some members of this family were of a much paler yellow (almost white) than in others. On this day the young were for the first time seen to make occasional flights into the lower branches of the tall trees. On the 29th we observed that one of the little birds of this brood (and so far as we could perceive, only one) had a triangular dusky area on the throat and a similarly colored patch on each cheek, in short was a young chrysoptera.

A few days later the scope of our field study was enlarged by the discovery of the whole family belonging to the third male Golden-wing that has been already mentioned as occupying a station on the edge of the swamp in the early summer. His mate proved to be a normal female Golden-wing and all the young were Golden-wings, with dusky throats and cheeks.

For the moment we were a little staggered as we thought of the complications that might arise from the presence of three broods within a comparatively limited area; but we were delivered from confusion by one feature in the life history of these birds: the integrity of the several families was absolutely maintained as long as the young were fed by their parents, and this condition endured up to about the twentieth of July.

The manner of making observations on these birds was as follows: On first entering the precincts of the swamp I would listen intently for the voices of the young birds. Their cricket-like chirping was incessant throughout the long period in which they were fed by the old birds and fortunately their notes were very characteristic and distinctive. The only sound in the swamp that could be mistaken for the voices of the hungry little Helminthophitae was that emitted by a young Cow-bird being fed by its foster-parents, a pair of Chestnut-sided Warblers. The chirp of the young Helminthophilae also resembled in no 
remote degree the cries of young Chipping Sparrows at a certain stage in their career. But there were none of these birds in the swamp to confuse one.

With this clue to the whereabouts of one of the families sought, a cautious approach would reveal one or both of the parent birds in their continual and indefatigable pursuit of food for the chirruping young. The source of the foodsupply was to some extent the foliage of the tall trees overhead, but chiefly the undergrowth of ferns and Raspberry vines. At first the life of the young birds was passed exclusively in the dense herbage and shrubbery near the ground, but by the twenty-sixth of Jume they had acquired strength and confidence enough to make occasional sallies into the trees, soon to return to their favorite haunt on the ground below. Here they would take frequent short flights of two or three rods, from cover to cover, displaying in their course the obvious white markings of the tail feathers. By standing perfectly still, sometimes on the vantage ground of a small hillock or stump, I would from time to time get a good view of one or another of the brood. When Dr. Tyler was with me, we would sometimes adopt the following method of getting a close observation of the young birds: one of us would sit upon the ground, completely hidden in the Cinnamon Ferns, while the other would slowly drive the little birds toward the place of concealment. By this ruse we now and then succeeded in getting observations at a marvellously short range, so short, indeed, that I had to discard my field-glasses and put on my reading-glasses.

On the approach of the parent bird with food, the youngling would receive it with accelerated chirps and quivering wings. In the intervals between the visits of the parents the young would condeseend to a little listless gleaning of food for themselves, at least after they were a few weeks old, but this did not scem to moderate in the least degree their demands upon their parents.

During some of our visits to the swamp we had all three of the families under observation within the space of two or thrce hours. As has been already pointed out, keys for the identification of the different families were furnished both by the adult and the young birds. In the group to which the nest belonged the father, a chrysoptera, was so much brighter in color than the father of the second family that he could be recognized at a glance; the young, moreover, were older and ever in a more advanced state of plumage. The third family was identifiable by the mother's being a chrysoptera and the young ones also chrysopteras, with dusky throats and ear-coverts, whereas both the other broods had leucobronchialis mothers and, with the exception of one individual of the second family, lacked the diagnostic markings of chrysoptera. 
If perchance two of these families met together in their movements to and fro through the swamp (we saw this happen only twice during our long watches) a momentary confusion would ensue, but this would be quickly dispelled by the segregation of the different family groups.

The range of these birds extended occasionally into the Gray Birch growth that abutted on two sides of the swamp. It was interesting to find that the open oak wood on the south, barren of any undergrowth, proved to be a barrier to their progress in that direction as effectual as the Bobolink meadow on the east.

A similar mode of life while rearing their young was followed by the numerous Veeries, Chestnut-sided Warblers, Oven-birds, Maryland Yellowthroats, and Indigo-birds, that inhabited the same swamp. The Black-and-White Warblers and Redstarts, on the contrary, took care of their broods up in the trees.

By the fourth of July the young birds belonging to the oldest brood had acquired in a large degree the first-winter plumage and were approximately as large as their parents. Their color is now gray above, tinged with olive, more especially on the rump and upper tail-coverts. Lores black, but the black color not easily traced behind the eye. Forehead yellow, as in the adult female leucobronchialis and chrysoptera. Below, dull ash, washed with yellow, including the throat. Wing-bars pale yellow. The breast has a patchy or spotty appearance, evidently caused by the transition from the darker juvenile to the lighter first-winter plumage.

On the tenth of July we saw at least three of the young of this family, when they appeared to be as large as their parents and were hardly distinguishable from them if it were not for the fact that the old birds were still busily engaged in feeding them, and that the characteristic chirruping of the young was still kept up. In fact the plumage of the young was now brighter than their mother's, their polls being more extensively yellow, their lower parts whiter. The wingbars which were double and widely separated in the juvenile plumage now seemed to be reduced to a single yellow bar. ${ }^{1}$

We have now followed up the brood which issued from the nest on the seventeenth of June to a point where they have essentially acquired the plumage of the adult, and we have seen them develop into pure Brewster's Warblers (i.e. in plumage). By keeping them under observation until the completion of the post-juvenal moult it has been demonstrated that they are not only not chrysopteras but not even transitional forms in any respect between chrysoptera and leucobronchialis, but leucobronchiales of extraordinary purity.

${ }^{1}$ Probably because one set of coverts had not yet been renewed after the post-juvenal moult. 
To return to the second family which we left on the twenty-ninth of June. This brood also, it will be remembered, was of mixed parentage, the father being a chrysoptera, the mother a leucobronchialis. On the eighth of July the young were well along in their progress to the first-autumn plumage. The one with the dusky throat and ear-coverts now shows the characteristic marks of $H$. chrysoptera, the dark ash, or slate-colored throat and upper breast being sharply defined against the ashy-white lower breast and sub-malar stripes which meet together on the chin. The dark areas on the sides of the head are likewise well defined. The crown is still olive-colored, the back gray, with a touch of olive. The other members of this brood of young birds have the under parts gray throughout, tinted with a varying amount of yellow in different individuals. This variability may be connected with sex, the female leucobronchialis being more distinctly charged with yellow than the male. No member of this brood, with the exception of the one above noted, showed any trace of the chrysoptera throat and cheek markings.

On the fourteenth of July I shot one of the young Brewster's Warblers belonging to this brood. The length of this specimen ${ }^{1}$ in the flesh, from the tip of the bill to the end of the tail, was 4.8 inches, wing 2.5 inches, tail 1.9 inches. Forehead and crown yellow, veiled posteriorly by the olive-green tips of the feathers; narrow supra-ocular line whitish; the rest of the upper parts gray tinged with olive; lores and a post-ocular spot black; rectrices slate-colored, the inner webs of the external pair extensively, of the second and third pairs entirely, white; ${ }^{2}$ primaries slate-colored, edged with gray; secondaries slatecolored, edged with olive; median and greater wing-coverts tipped with yellow; these coverts have not yet completed their growth after the post-juvenal moult, many of them still being in the shape of sprouting pin feathers; under parts white, lightly washed with yellow, especially on the breast, and with a faint tinge of ash on the flanks. Dr. H. W. Rand, who kindly sexed this specimen for me, reports it to be a male.

By the seventeenth of July the young of this brood appeared to have assumed their full winter dress. The young chrysoptera differed from his father merely in having the yellow of the crown and gray of the back washed over with olive, and the sub-malar white stripes of the right and left sides united on

${ }^{1}$ Fig. 1 on the accompanying plate. Coll. MIus. Comp. Zoöl., No. 48385.

${ }^{2}$ Mr. C. J. Maynard (Warblers of New England, 1904, p. 85-85) sets great store by the caudal colorpatterns in Helminthophila pinus, $H$. chrysoptera, and the closely related forms $H$. leucobronchialis and H. lawrencei. I do not believe that the tail markings in these birds signify anything beyond a large range of individual variation. 
the chin. All the rest of this brood, like the one shot on the 14 th, were leucobronchiales.

At this date (July 17) the young birds, though still receiving food from their parents, feed themselves freely, both in the trees and in the underbrush, where we sometimes observed them basking with outstretched wing in a spot of sunlight. They are now more silent than before and their peculiar infantile chirp has become distinctly transformed into a note resembling the chirp of the adult bird.

It now remains briefly to consider the third family of Helminthophilae. The parents in this case were both normal Golden-wings and all of their young, so far as we could discover, were also Golden-wings. Observations taken on the seventeenth of July disclosed the young in their autumnal dress. One at least was a female, with the throat and sides of the head of a very light gray color, but clearly marked off by the much whiter hue of the breast, submalar and supra-ocular stripes. The majority of the young were males, now similar to the adult male in plumage, but more olivaceous on the back; the black throat and cheeks slightly veiled by a yellowish wash; the sub-malar stripes, too, met each other broadly under the bill, while in the adult male, as was the case in the other two families, the chin was black throughout. At such close range were some of these birds observed (July 18) that I could see through opera-glasses the sprouting feathers of the wing-coverts as plainly as if the bird were in my hand.

About the twentieth of July the bonds which held these little families together were broken. The change was startlingly abrupt. In passing through the swamp we were no longer greeted by the chirrupings of the little birds. From time to time we might detect a chrysoptera or a leucobronchialis or two, perhaps in company with some other kind of warbler, feeding silently, well up in the tree-tops, but in most cases it was impossible to decide whether it was an old or a young bird. . On two occasions, on the 18 th and 20 th of July, I heard a chrysoptera sing three or four times in succession the longer second song of this species; this was the only singing of these birds noted since the chrysoptera stopped singing on the sixth of June and the leucobronchialis on the twenty-fourth. The Brewster's Warblers were seen for the last time on August 7; one or two Golden-wings were seen on August 8, and a single male on August 21.

In order to form a judgment concerning the probability of some of the conclusions arrived at in the foregoing pages the reader should be aware of the amount of time spent in making the observations. From the time the young 
birds of the earliest brood left the nest, June 17 , to the 20th of July when the opportunities for observing were lost on account of the dispersal of the families is a period of 34 days. I devoted a portion of twenty-four of these, amounting altogether to upwards of 75 hours, to the study of these birds. If now it be borne in mind that for a month or more after leaving the nest the young are constantly fed by the parents and most assiduously by the male, the inference that the male leucobronchialis was unmated is irresistible. That there was but one chrysoptera in the second brood observed is not so certain, but probable in the highest degree. At all events a large majority of this brood were leucobronchiales.

Since Helminthophila leucobronchialis was first described by Mr. Brewster in 1S74, almost every conceivable hypothesis has been advanced by one writer or another to fix its true status in our bird-fauna. And yet it remains one of the most perplexing of ornithological problems. It was at first treated as a valid species, but its rarity, its association with $H$. pinus or $H$. chrysoptera, its intergradation with one or the other of these species, especially the former, by a series of intermediate forms, the peculiarity of its distribution, and the fact that it possesses no peculiar characters which are not found in either one or the other of the two species mentioned, ${ }^{1}$ led soon and inevitably to the theory that it is nothing else than a hybrid produced by the union of $H$. pinus and $H$. chrysoptera. Mr. Brewster himself was one of the earliest advocates of this theory and he has consistently adhered to it up to the present time. In the Bulletin of the Nuttall Omithological Club, 1881, 6, p. 218-225, he gave his reasons for thinking that $H$. leucobronchialis and $H$. lawrencei both were hybrids of $H$. pinus and $H$. chrysoptera, the two forms being produced by a reversal of the sexes in crossing, like the mule and the hinny.

In the Auk, 1885, 2, p. 359-363, Mr. Ridgway while admitting lawrencei to be a hybrid between pinus and chrysoptera held to the view that leucobronchialis was a distinct species, which by interbreeding with pinus produced the various intermediate stages connecting leucobronchialis with pinus, and by interbreeding with chrysoptera produced the extremely rare forms which combine characters of leucobronchialis and chrysoptera. A few years later (Manual N. A. Birds, 1887, p. 486), Mr. Ridgway deemed it more likely that leuco-

${ }^{1}$ Mr. Ridgway, Dr. Bishop, and Mr. Chapman have maintained that the white throat of Brewster's Warbler is a peculiar character not found in either the Blue-winged or the Golden-winged Warbler. Although this is technically true it does not seem to me to bear against the theory that Brewster's is a hybrid between the Blue-winged and the Golden-winged Warblers. If the Golden-wing transmitted the white ground color of the lower parts without transmitting the black throat one would expect the hybrid to have a white throat. 
bronchialis and lawrencei were dichromatic phases - the former a leucochroic or white phase of pinus, the latter a xanthochroic or yellow phase of chrysoptera.

Dr. Bishop in the Auk, 1905, 22, p. 21-24 adopts Ridgway's theory that leucobronchialis is a white color-phase of pinus but sticks to the older belief that lawrencei is a hybrid.

The old notion that leucobronchialis is a true species has been pretty generally abandoned although it is still held by Messrs. C. J. Maynard and W. E. D. Scott. Mr. Maynard (Birds of Eastern North America, Revised Edition, 1896, p. 577-578, Warblers of New England, 1904, p. 83-88) believes that Brewster's and Lawrence's Warblers are both species of very recent origin, which have arisen as offshoots from $H$. chrysoptera. The late Mr. Scott on the other hand (Science, 1905, 22, p. 273-281) thought that the two lately-evolved species had originated as mutants from $H$. pinus.

Finally, Dr. C. W. Townsend, in the Auk, 1908, 25, p. 65-68, as an alternative to the theory of the hybrid origin of Brewster's Warbler, suggests the possibility of its being an atavistic phase of the Golden-wing which may perhaps in some cases develop a black throat in the second-winter plumage, like a Redstart (Setophaga ruticilla).

I do not see that there is anything left for a new aspirant to honors in guessing unless it be the conjecture that Helminthophila pinus and Helminthophila chrysoptera are themselves nothing but southern and northern dichromatic forms of one and the same species!

The published observations that have any bearing on the status of Brewster's and Lawrence's Warblers fall naturally into two categories: first, direct observations indicating the nuptial alliances of either Brewster's or Lawrence's Warblers, or of the Blue-winged with the Golden-winged Warbler; second, observations of young birds one of whose parents alone was seen but whose plumage nevertheless betokened a mixed parentage. To the first category belong the following:

1. Chapman, Auk, 1887, 4, p. 348. Englewood, N.J. Leucobronchialis o , shot, June 26, 1887. At the same time and place a pinus or feeds four young, three of which were shot and proved to be pinus. [These young are well along in their autumn plumage and are certainly pinus. The leucobronchialis was of course probably their mother.]

2. Eames, Auk, 1888, 5, p. 427. Seymour, Conn. Leucobronchialis or and pinus ( $q$ ?) associated together, June 3 et seqq., 1888, the only Helminthophilae seen in the locality. 
3. Sage, Auk, 1889, 6, p. 279. Portland, Conn., June 13, 1889. Pinus o and chrysoptera o engaged in visiting a nest and feeding five young in juvenile plumage. These were all collected. [They will be described further on.]

4. Eames, Auk, 1889, 6, p.307. So. Conn. Leucobronchialis or and pinus of feeding young, June 24, 1889. The young looked like pinus.

5. Chapman, Auk, 1892, 9, p. 302. Englewood, N. J. Leucobronchialis \&, washed with yellow below, wing-bars white $[i . \ell$. an intermediate between leucobronchialis and pinus] flushed from nest and joined by a typical pinus $\sigma^{7}$, who shared her anxiety. June 12, 1892. Nest afterward deserted.

6. Eames, Auk, 1893, 10, p. 89. Bridgeport, Conn., June, 1892. Leucobronchialis $\sigma^{7}$ with pimus of for a mate [no evidence that they were mates adduced, there was a lawrencei or within a stone's throw]. Nest found. Two young hatched in this nest were like the young of pinus when they left the nest. [Leucobronchialis and pinus look very much alike at the time they leave the nest.]

7. A. H. Verrill, Auk, 1893, 10, p. 305. New Haven, Conn. Lawrencei breeding. Six young in nest, June 5, 1893. [Unfortunately no detailed observations are recorded in this case to show clearly whether both parents were lawrencei.]

8. Sage, Auk, 1895, 12, p. 307-308. Portland, Comn., June, 1894. Leucobronchialis of [grading toward pinus] and chrysoptera or (o flew to of occasionally), nest, and eggs. Both birds, nest and eggs collected.

9. Bildersee, Bird Lore, 1904, 6, p. 131-132, Beebe, Auk, 1904, 21, p. 387-388.

Bronx Park, N. Y. Lawrencei or mated with pinus of, nest with six young. [Mr. Beebe says these young in the nest June 13, 1904, were all in the typical nestling plumage of $H$. pinus. Mr. Bildersee describes them with some detail. On the fourteenth of June they showed traces of yellow on the breast, the jugulum and middle of the belly were bare, the wing-bars white. I do not understand why they were identified as pinus rather than lawrencei.]

10. Bishop, Auk, 1905, 22, p. 23. New Haven, Conn. Pinus or nesting with chrysoptera o, Miay 23, 1895 (teste A. H. Verrill). [No details.]

11. Bishop, Auk, 1905, 22, p. 24. Pinus or mated with o intermediate between chrysoptera and lawrencei (teste A. H. Verrill). May 21, 1902. [No details.] 
12. Meeker, Auk, 1906, 23, p. 104. Bethel, Conn., June, 1906. Chrysoptera $\checkmark$, pinus $q$, nest and five young. [One of them found, June 16, after leaving the nest, appeared to be a typical young pinus. A pinus or was also present. Neither of the males was seen to feed the young, nor is it stated that either male was seen feeding the female. Proof as to which male was the mate of the female in this interesting case is therefore lacking in the published record. Moreover, pinus and leucobronchialis look so much alike at the time they leave the nest, that the author's identification of the young bird as pinus is of no value unless he is very familiar with leucobronchialis in juvenile plumage.]

13. Granger, Auk, 1907, 24, p. 343, Faxon, Auk, 1907, 24, p. 444, Maynard, Warblers of N. E., Addenda, 1908, p. 139-140, pl. xuI. Jamaica Plain, Mass., June, 1907. Leucobronchialis or mated with chrysoptera o , nest and young.

14. Maynard, Rec. Walks and Talks, 1908, 1, p. 79-80, Sherman, Auk, 1910, 27, p. 444. Jamaica Plain, Mass., June, 1908. Leucobronchialis or mated with chrysoptera o. [Same locality as No. 13.]

15. Peters, The Wren, 1909, 1, p. 45. Braintree, Mass. Chrysoptera $0^{7}$ and leucobronchialis $\&$, nest and young which died in the nest.

16. Bishop, Auk, 1910, 27, p. 464. Woodmont, Conn. Lawrencei or probably mated with pinus o, nest and four eggs; all were collected; June 4, 1909.

To these sixteen cases are now to be added the two treated of in this paper, both of them being cases of the union of chrysoptera $\sigma^{7}$ with leucobronchialis $\$$.

Among observations belonging to the second category, i.e., of young birds one of whose parents alone was seen but whose plumage nevertheless pointed to a mixed parentage I have noted the following:

1. Brewster, Bull. N. O. C., 1881, 6, p. 220-221. Highland Falls, N. Y., July 7, 1879. Lawrencei o with a young one which is clearly a leucobronchialis.

2. Fisher, Auk, 1885, 2, p. 378-379. Sing Sing, N. Y. Chrysoptera o feeding young with first-autumn plumage of pinus, July 4, 1885, yellow below, wing-bars white [Coll. J. E. Thayer, no. 8775]. Another of the young resembled the mother, no yellow on the breast.

3. Bishop, Auk, 1894, 11, p. 79-80. New Haven, Conn. Leucobronchialis ( o ?) feeding two young, July 4 , apparently $H$. pinus. In one the wing-bars were white, in the other they were broader and light yellow. 
4. Voorhees, Auk, 1894, 11, p. 259-260. Lawrencei o feeding first plumage [? ] young, July 12, 1893, which appeared to be pinus; showed clearly the well defined black lores of pinus. [From the date and description, these young were probably in first-autumn plumage.]

5. Dwight, Sequence of Plumages, Ann. N. Y. Acad. Sci, 1900, 13, p. 246. Englewood, N.J. Pinus feeding two young, one of which is pinus, the other lawrencei, June 28, 1897.

In dealing with the observations pertaining to the first category one is seriously embarrassed in many cases by the insufficiency of the evidence adduced to show that the birds observed were mated. In some cases, indeed, the observer has failed to give any facts whatever to establish the conjugal relation, whatever good evidences he may have had and withheld from publication. This is very regrettable in a matter of so much interest. To one who has perused the foregoing pages it will be clear that the mere association at a certain time of a male and a female is not enough to prove that they are paired. In the lack of a protracted series of observations the evidence of conjugal union obtained by seeing the male feed the female, or the male and female feed the young will be accepted by every one who is familiar with the life of these birds as conclusive, - as conclusive, in my estimation, as the witnessing of coitus.

Application of rigid tests will show that probably not more than one half of the eighteen recorded cases, given on page 68-70, are certain. The others must be regarded as probable, some of them, in fact, as merely possible. All of the records may be summarized as follows:-

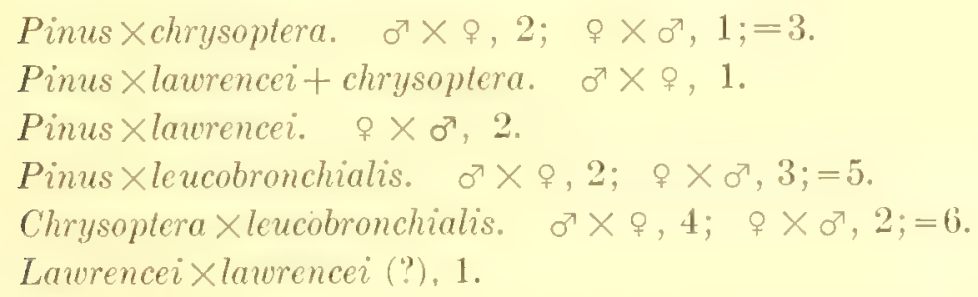

It appears from the above summary that although eleven cases, more or less well authenticated, of the mating of Brewster's Warbler have been observed, yet in not a single instance has it been found matched with another Brewster's Warbler. ${ }^{1}$ The union was always with either a Blue-winged Warbler or with

'No particulars concerning the Lawrence's Warbler found breeding near New Haven, Conn., June 5, 1893 (A. H. Verrill, Auk, 1893, 10, p. 305) are given, so that we are left in the dark as to whether this was a genuine case of a "hybrid" mated with a "hybrid." 
a Golden-wing. ${ }^{1}$ When one considers the number of Brewster's Warblers that have been found in certain parts of Connecticut, these misalliances can hardly be attributed to accident. They go to make a strong case against the theory that Brewster's Warbler is a valid species. So, too, the state of affairs disclosed in the Lexington swamp, where a beautiful male Brewster's Warbler failed to secure a mate while two female Brewster's Warblers mated with Golden-wings. This bears with equal weight, moreover, against the view that Brewster's Warbler is a color-phase of the Blue-wing, a view that implies the failure of the male to secure a mate although competing with males of another species. Why, furthermore, if leucobronchialis be an albinistic form of pinus should the white wing-bars of pinus be transformed into the yellow wing-bars of leucobronchialis?

Dr. Townsend's suggestion that leucobronchialis may be a dimorphic form of chrysoptera is opposed to the fact that the former is rarely found where the latter is a common bird, but usually where pinus is common, and where the distributional areas of pinus and chrysoptera meet.

To the hypothesis that Brewster's Warbler is a hybrid resulting from the union of the Blue-wing and the Golden-wing I can see no objections. A very large majority of the specimens of Brewster's Warbler that have been discovered have been found in regions like the State of Connecticut where the ranges of the Blue-wing and the Golden-wing overlap. The sporadic appearance of lencobronchialis in a region like Eastern Massachusetts is amply accounted for by the occasional occurrence of pinus in the same region.

In a suggestive note published in the Auk, 1908, 25, p. 86, Mr. J. T. Nichols shows that in case of a union of $H$. pinus with $H$. chrysoptera, if we assume that the white ventral color of chrysoptera and the plain throat of pinus play the part of dominants in transmission, by Mendel's Law of Heredity the offspring, $F_{1}$, should all be Brewster's Warblers in plumage. Adopting Mr. Nichols's system of symbols, let W stand for the dominant white under parts of chrysoptera, $\mathrm{W}$ for the recessive yellow of pinus; let $\mathrm{P}$ stand for the dominant plain throat of pinus, while $\mathrm{p}$ represents the recessive black throat of chrysoptera. Then:

${ }_{1}^{1}$ Mr. C. J. Maynard (Warblers of New England, Addenda, 1908, p. 139-140; Record of Walks and Talks, 1908, 1, p. 79) and Mrs. J. W. Sherman (Auk, 1910, 27, p. 444) by some strange vagary have identified the mates of the male Brewster's Warblers that bred in the Arnold Arboretum, Jamaica Plain, Mass., in the summers of 1907 and 1908, as female Brewster's Warblers. They were in reality Goldenwinged Warblers in very high plumage, the throat patch being uncommonly dark for the female, and the upper border of the ash-colored cheek patch deepened into a dusky hue. Mrs. Sherman has added to the confusion by publishing in the Auk, 1910, 27, p. 443-147, an account of a pair of Goldenwinged Warblers found breeding in Roslindale, Mass., in June, 1910, which she was deluded into believing to be a male Golden-wing and a female Brewster's Warbler! A female Brewster's Warbler does not have a dusky nor a gray throat patch, neither does it have a gray cheek. 


$$
\begin{aligned}
& \text { P w (pinus) } \times \mathrm{p} \mathrm{W} \text { (chrysoptera) } \\
& F_{1} \quad \text { P w p W }
\end{aligned}
$$

That is, the offspring of the first generation will all be impure dominants, but in plumage P W, leucobronchialis. If two of these hybrids of the first generation should mate together and produce offspring the second filial generation would comprise Brewster's Warblers, Blue-wings, and Golden-wings, and also the pure recessive, Lawrence's. Warbler ( $\mathrm{pw} p \mathrm{pw}$ ), in the relative numerical proportion of $9,3,3,1$. But we have seen that as far as observations show, Brewster's Warbler always breeds back with one of the hypothetical parent forms, pinus and chrysoptera. In that case the advent of Lawrence's Warbler will be deferred to the third filial generation when it will come to light in small numbers as compared with the dominant hybrid, Brewster's Warbler.

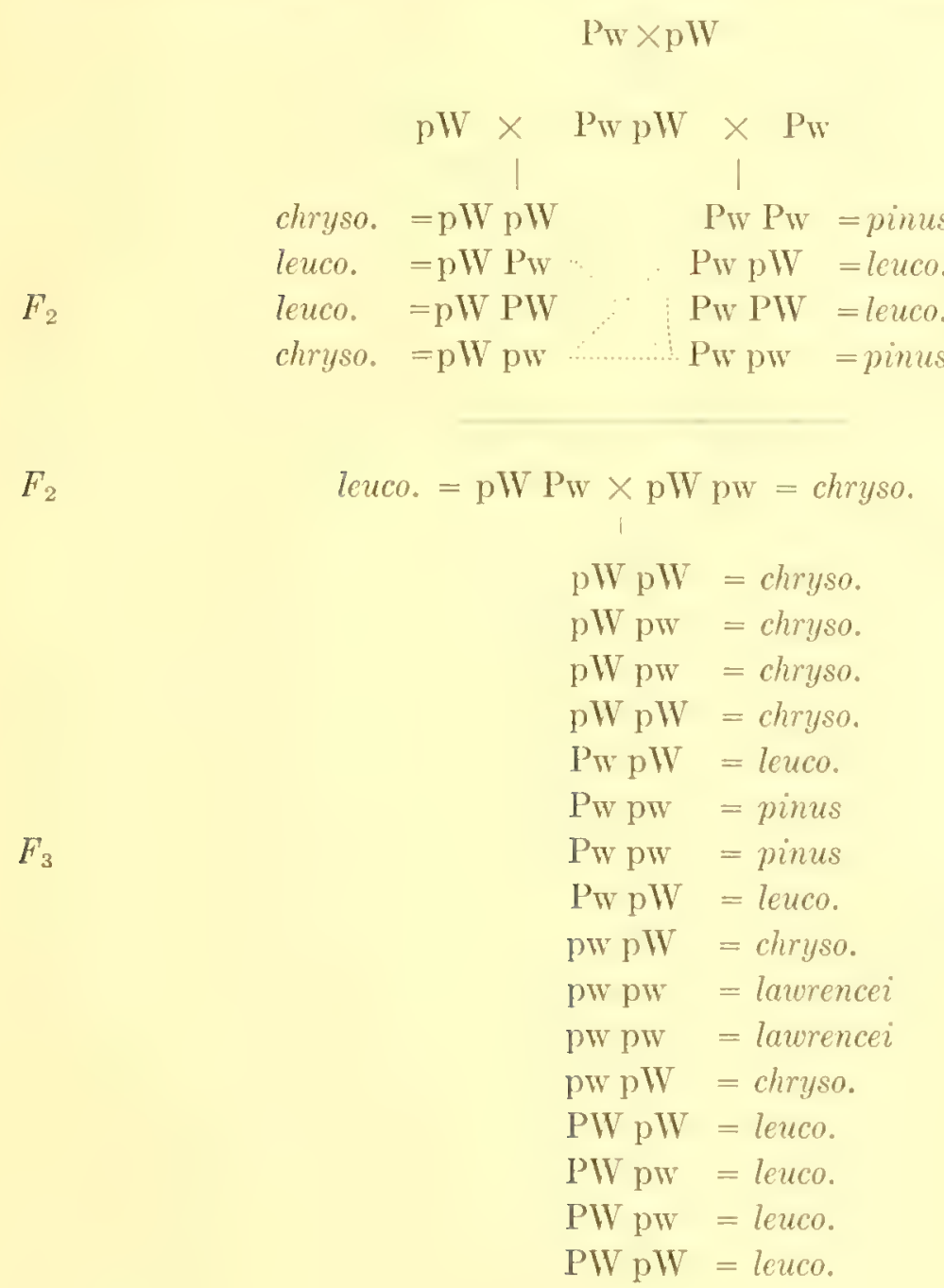


That is, if an $F_{2} \mathrm{pW}$ pw (in plumage a chrysoptera) mate with the hybrid pW Pw (leucobronchialis) of the same generation, their issue would be, on the average, chrysoptera, leucobronchialis, pinus, and lawrencei in the relative proportions of $3: 3: 1: 1$. The only other possible unions which could produce Lawrence's Warblers, if the union of two Brewster's Warblers be debarred, are indicated above by the dotted lines, - altogether five combinations out of twenty-two possibilities. It is evident, therefore, that Lawrence's Warbler, by this theory of its origin, must ever be a very much rarer bird than Brewster's Warbler, and that such is really the case is well established by the records. The hybrid theory illumined by the Mendelian Law of Heredity accounts not only for the existence of Brewster's and Lawrence's Warblers but also for the relative abundance of these two extraordinary forms. What more should be required of a working hypothesis?

I regret that the crucial test afforded by the mating of $H$. pinus with $H$. chrysoptera was not presented for study in Lexington last summer. The chances of meeting with a case of this sort here are very remote, $H$. pinus being so rare as almost to be classed as accidental. In place of the union of the two hypothetical parent species I had in both cases to deal with the union of the hypothetical hybrid, $H$. leucobronchialis, with one of the parent species, H.chrysoptera. The results were not devoid of interest. As has been shown, the offspring were all like one or the other of the parents, $i . e$. they were either leucobronchiales or chrysopterae. There were none that showed characters intermediate between the parents. In other words Mendel's Law of Dominance was operative."

By our theory the union of an $F_{1}$ leucobronchialis with a pure chrysoptera should produce a mixed brood of leucobronchiales and chrysopterae and this was the composition of one of the two broods of mixed parentage whose history has been detailed in the foregoing pages. The same result would ensue from other combinations, e.g. an $F_{2}$ leucobronchialis, $\mathrm{pW}$ PW, mated with an impure chrysoptera, $\mathrm{pW}$ pw.

${ }^{1}$ It is a curious fact that intermediates between leucobronchialis and chrysoptera are almost unknown. Mr. Brewster (Bull. Nuttall Orn. Club, 1S81, 6, p. 219. and Dr. Fisher, (Id., p. 245) have recorded a specimen of lencobronchialis with black auriculars like chrysoptera; Mr. Ridgway in his article in the Auk, $1885,2, \mathrm{p} .363$, seems inadvertently to have referred to this case as two. Dr. Townsend (Auk, 1908, 25, p. 65-66) mentions a female leucobronchialis in Mr. Brewster's collection with faint grayish cheek patches. On the other hand leucobronchialis, especially in Connecticut, grades into pinus by a complete series of intermediates. Whether the Law of Dominance would cease to operate as $a$ result of long continued breeding-in of the hybrid with pinus I leave to the consideration of those who are better versed in Mendelism than I am. I have little doubt, after surveying the whole genus Helminthophila and taking into account the color of the juvenile plumage of all the species, that the yellowish under parts are an ancestral feature. That an ancestral character should be suppressed as a recessive at the first crossing is not remarkable. The same thing has been shown to happen in crossing breeds of barn-yard fowl. 
A homogeneous brood of leucobronchiales, like the other brood of mixed parentage I studied, might be the progeny of an $F_{2}$ loucobronchialis, PW PW, mated with a pure chrysoptera or of a pure leucobronchialis, PW PW, (if there be such a thing ${ }^{2}$ ) mated with any chrysoptera. Or it is possible that the homogeneity of this brood arose from the number of young being too small to calculate averages from, or in other words too few to show the possible range of variation.

Other instances of the prevalence of the Law of Dominance in the inheritance from mixed unions are furnished by the published records. Mr. Chapman's case (No. 1, p. 68) of pinus or mated with leucobronchialis o was pretty well established. Three of the young which were shot June 26 were young pinus, and a leucobronchialis secured in the same spot at a later date Mr. Chapman thinks may have been the remaining bird of this brood.

$$
\begin{aligned}
& \mathrm{Pw} \mathrm{pW} \times \mathrm{Pw} \\
& 2 \text { leuco., } 2 \text { pinus }
\end{aligned}
$$

Brewster, (case 1, p. 70). Laurencei of with a leucobronchiatis juv. The father in this case was probably a leucobronchiatis.

$$
\begin{gathered}
\text { pw pw } \times \text { Pw pW } \\
\text { pinus, chryso., leuco., } \\
\text { lawrencei, in equal nos. }
\end{gathered}
$$

If a pure leucobronchialis (PW P'W) all the young should be leucobronchiales. Fisher, (case 2, p. 70). Chrysoptera of feeding a young pimus. Another of the young resembled the mother. This may have been a case of an impure chrysoptera ( $p w p W$ ) mated with an impure pinus (pw Pw). The offspring in this case should include chrysoptera and pinus in equal proportion.

Bishop, (case 3, p. 70). Leucobronchialis feeding two young (July 4), apparently $H$. pinus. In one the wing-bars were white, in the other they were broader and light yellow [leucobronchialis?]. The unknown parent in this case was probably a pinus. Cf. case 1, Chapman, p. 68 .

Dwight, (case 5, p. 71). Pinus feeds young, one of which is pimus another lawrencei. An impure pinus, pw Pw, mated with a lawrencei, pw pw, should produce young pims and lawrencei in equal numbers, by Mendel's Law.

It has been already noted on page 69 that $\mathrm{Mr}$. Sage had the good fortune

\footnotetext{
${ }^{1}$ A pure leucobronchialis, PIV, in the Mendelian sense, must be the off spring of a pair of leucobronchiales, a conjunction never yet observed.
} 
to discover a chrysoptera mated with a pinus breeding at Portland, Conn., in June, 1889. Five young, the issue of this pair, were secured the day they left the nest, and they have been kindly loaned to me by Mr. Sage (Coll. J. H. Sage, nos. 1321-1325, 2 \%, 3 \% ; one of these, no. 1321, is represented on the Plate, fig. 4). There is but slight variation in color amongst them. They are grayish olive on the crown, sides of the head, and back. The chin, throat, breast, and flanks are grayish olive, lighter than the back. The median part of the belly yellow. Remiges slate brown, edged with whitish and olive. Wing-bars olive-yellow. Young $H$. pinus of the same age, for the use of which I am indebted to Dr. J. Dwight, Jr., and Mr. William Brewster, ${ }^{1}$ are olive on the crown, sides of the head and back, yellow-olive on the chin, throat, breast and flanks, yellow on the belly. The remiges are slaty brown edged with whitish olive. The wing-bars are oliveyellow. Compared with Mr. 'Sage's birds the young pinus are distinctly different, being more deeply suffused with yellow throughout.

I have no skins of the Lexington Brewster's Warblers in their juvenile plumage to compare with the young of pinus and with Mr. Sage's specimens. Since it was my object to determine what each one of the young birds developed into as adults, none were killed before attaining the first-winter plumage. Nevertheless, careful notes of the color of the young birds, taken when they had just quit the nest, reinforced by a vivid recollection of their appearance, convince me that they were like Mr. Sage's birds, distinetly grayer than the young of pinus. How do these young birds in their juvenile dress, that is, young pinus and Mr. Sage's birds, compare with the young of chrysoptera at the same age? I have been able to obtain but two specimens of chrysoptera in juvenile plumage, one from Mr. Brewster (No. 4669, Highland Falls, N. Y.) and one from the Carnegie Museum, Pittsburg, Pa. (No. 7100, Beaver Co., Pa., W. E. C. Todd), ${ }^{2}$ and these are both considerably older and larger than the young pinus and the Sage birds, their tails being 1.1 inches in length. The Carnegie Museum specimen is shown on the plate, fig. 2. Their crowns, and the sides of their heads are dull olive-brown; back a shade or two darker; chin, throat, breast, fore belly, and flanks dull olivaceous ash; middle of belly and vent whitish; tail slatecolored with the three external pairs of quills extensively white on the inner webs; remiges slaty brown, edged exteriorly with olive, middle and greater wing-coverts tipped with yellowish. The black lores of the following first-

I One of Dr. Dwight's specimens is shown in Fig. 3 of the accompanying plate.

${ }^{2}$ I would also acknowledge the courtesy of Mr. F. M. Chapman of the American Museum, New York, and Mr. H. C. Oberholser of the U. S. Biological Survey, Washington, who have sent me skins of young Helminthophilae to examine. 
winter plumage are already beginning to show in the form of small, sprouting pin feathers. There is no trace of the throat-and check-patches in this plumage but the color that overspreads the chin, throat, breast, fore abdomen, and flanks is many shades darker than in even Mr. Sage's specimens. The dorsal surface, too, is darker, while the middle line of the posterior part of the abdomen is whiter,- less heavily tinted with yellow. As the chrysopterae are considerably older, the differences in the colors may be in part due to the wear of the delicate juvenile feathers or to the exposure of the deeper parts of the feathers as the body of the bird enlarges. Mr. Outram Bangs has pointed out to me that a change in color such as is here assumed, involving a passage from a lighter and yellower to a darker and more ashy hue, really takes place in the juvenile dress of Helminthophila rubricapilla as the young bird grows. Observations made by Mr. C. J. Maynard, moreover, confirm me in this belief. In his "Warblers of New England," 1901, pp. 77, 80, Mr. Maynard describes the first plumage of $H$. chrysoptera, at the time of leaving the nest, as "pale golden ashy throughout, lighter on the abdomen. Tips of two rows of wing-coverts, golden, forming two wing-bars." This description was made by Mr. Maynard in the field, while the little birds were perched on the fingers of a friend. Now this deseription of the color of the earliest stage of the chrysoptera in its juvenile plumage does not well apply to the two older specimens of chrysoptera whose skins I have before me, but fits the Sage specimens pretty well. I am therefore led to believe that the latter are either chrysoptera or leucobronchialis, and not pims for the reasons stated above. On a priori grounds one would expect the young of these two forms, chrysoptera and leucobronchialis, to be indistinguishable when they leave the nest, since except for the dark throat and ear patches (which do not appear until the first-autumn plumage) the adults of these two forms are alike.

Thus, through the lack of sufficient observations bearing on the relations of the birds under discussion, and the meagre material in collections to throw light upon the juvenile plumages, one is foiled at every step in this investigation. What is now wanted is for some one to follow up a young brood, the progeny of a pinus and a chrysoptera, until they have assumed the first-winter dress and so revealed their identity. To do this in the field is a long and laborious task and the circumstances may not always be such as ensure success. It were highly to be wished that experiments in breeding pinus with chrysoptera in an aviary would be undertaken in some place like Bronx Park, where facilities for such experiments are furnished. Yet even in that case grave difficulties are bound to present themselves. Unless each species is secured in a region where the 
other is unknown, the experiments may be complicated and obscured through the chances of impurity of the parent stock. The long twelve-month intervals between successive generations, too, would place further obstacles in the path of him who tried to solve this problem by breeding the birds in confinement.

Mr. Brewster, arguing in 1851 in favor of the hybrid theory of H. leucobronchialis, closed his brief with the following words: "The bars are down; the gate stands open; 'he who runs may read.'" Yes, the gate stands open, but what I read is a sombre inseription over the portal:

LASCIATE OGNI SPERANZA, VOI CH' ENTRATE! 
EXPLANATION OF PLATE. 
Fig. 1. Helminthophita leucobronchialis. $\sigma^{T}$. First winter plumage, Lexington, Mass., W. Faxon, July 14, 1910. Coll. Mus. Comp. Zoöl., No. 48385. The father of this bird was H. chrysoptera of typical plumage, the mother a typical $H$. leucobronchialis. $\times 1$.

Fig. 2. Helminthophila chrysoptera. Juvenile plumage. Beaver, Pa., W. E. C. Todd, June 19, 1900. Coll. Carnegie Mus, No. $7100 . \times 1$.

Fig. 3. Helminthophila pinus. \%. Juvenile plumage. Near New York City, July 5, 1889. Coll. J. Dwight, Jr., No. $2285 . \times 1$.

Fig, 4. Helminthophila (offspring of $H$. pinus $\sigma^{7}$ and $H$. chrysoptera $\&$ ). $\sigma^{x}$. Juvenile plumage at time of quitting the nest. Portland, Conn., June 13, 1889. Coll. J. H. Sage, No. 1321. $\times 1$. 
MEM MUS COMP ZoOL

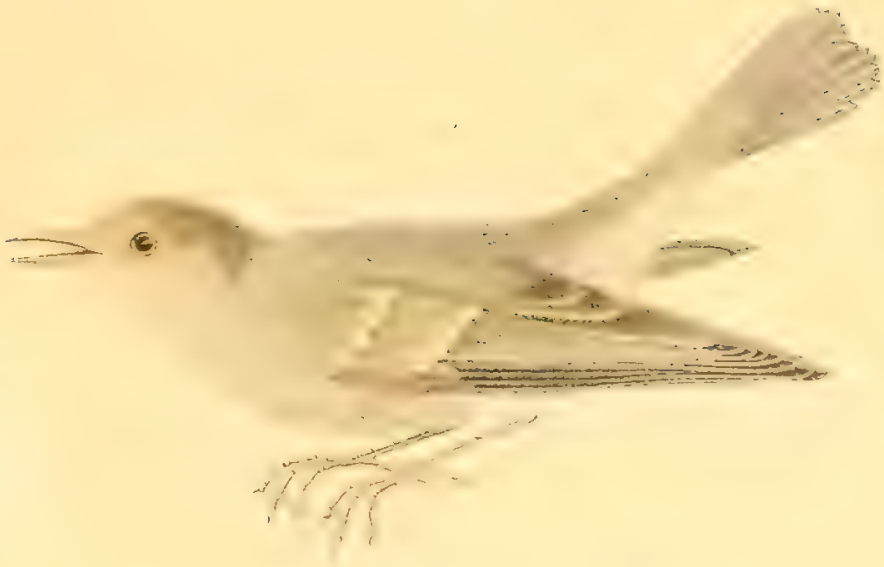

rum sune
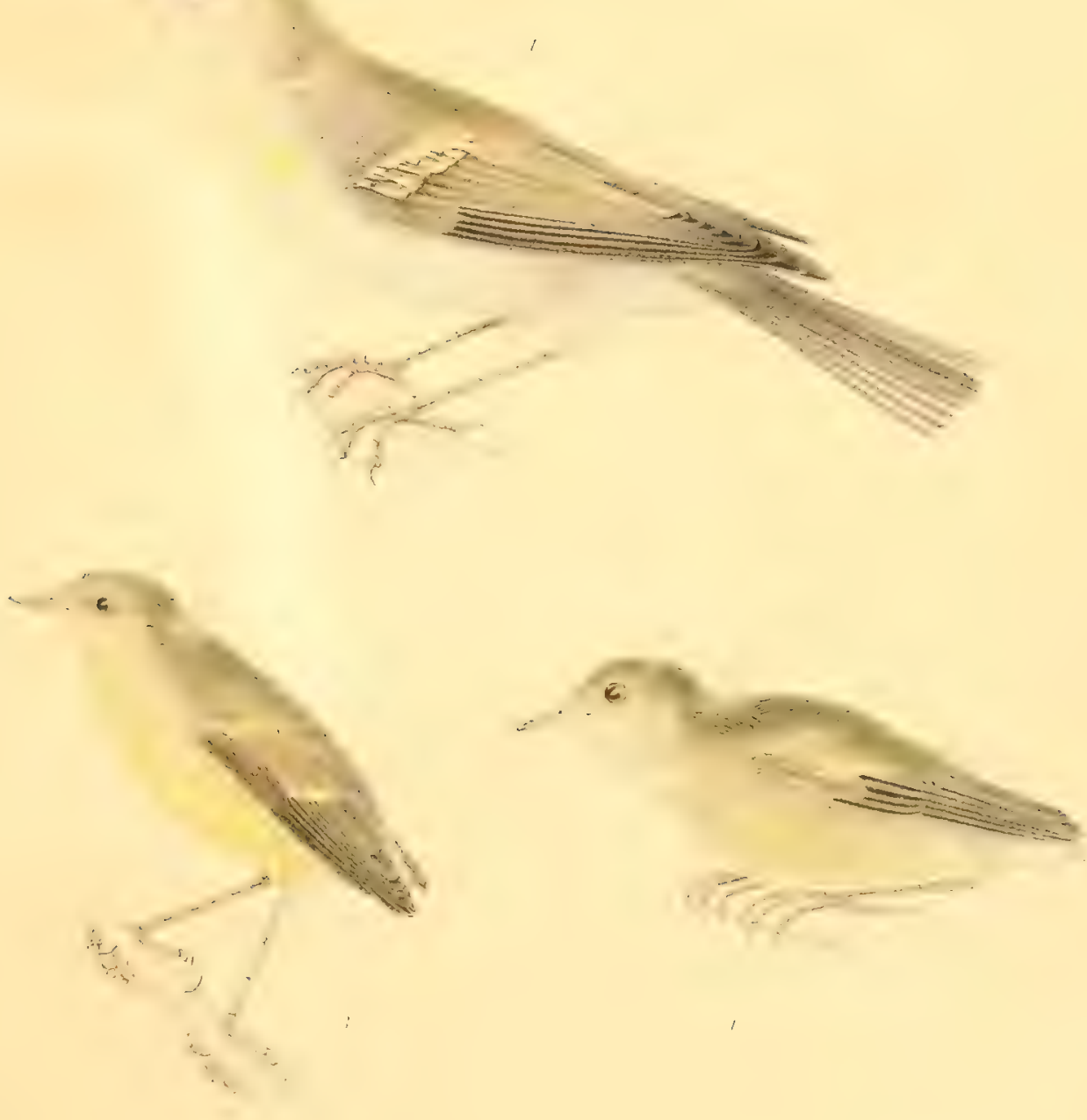


PUBLICATIONS

OF THE

\section{MUSEUM OF COMPARATIVE ZOÖLOGY}

AT HARVARD COLIEGE.

There have been published of the Bulletin Vols. I. to LII.; of the Memorrs, Vuls. I. to XXIV., and also Vols. XXVIII., XXIX., XXXI. to XXXIII., XXXVII, and XLI.

Vols. LIII. to LV. of the Bulletin and Vols: XXV. to XXVII., XXX., XXXIV. to XXXVI., XXXVIII. to XL., XLII. to XLVII. of the Mevorns, are now in course of publication.

A price list of the publications of the Museum will be sent on application to the Curator of the Museum of Comparative Zoölogy, Cambridge, Mass. 
12

- -2

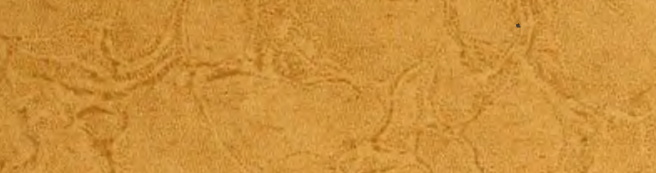

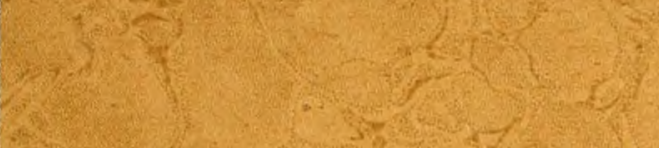

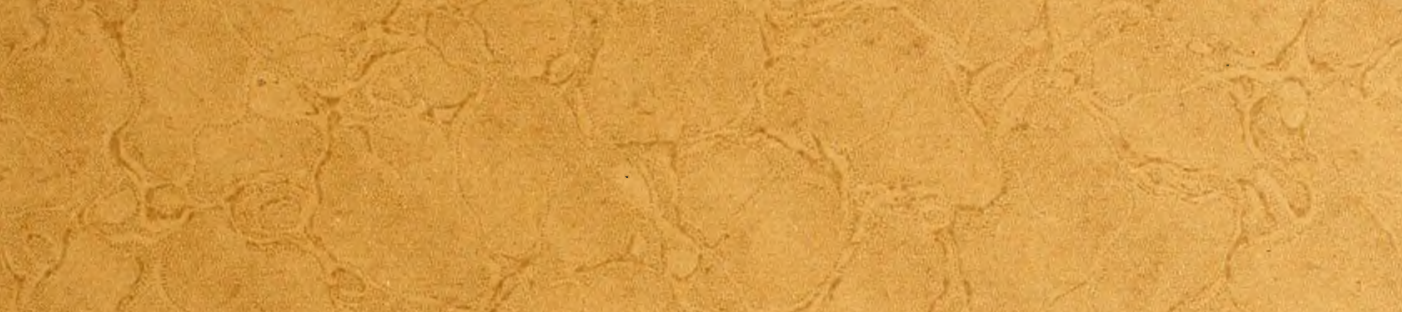

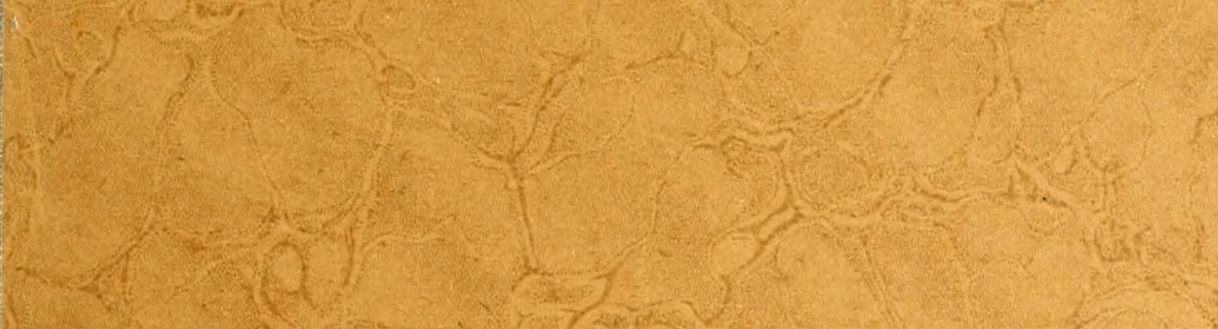

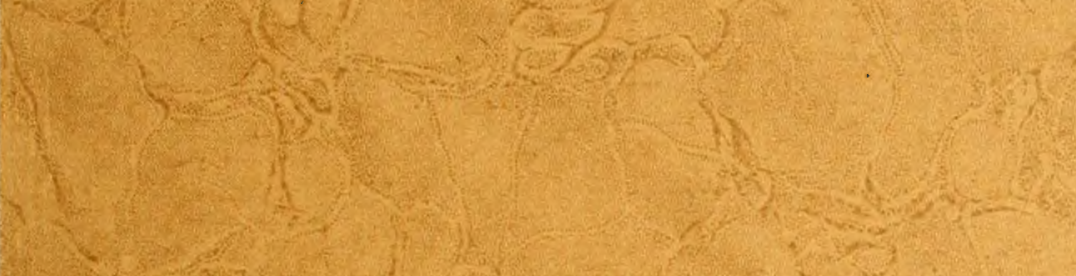

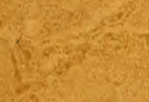

(-) 1

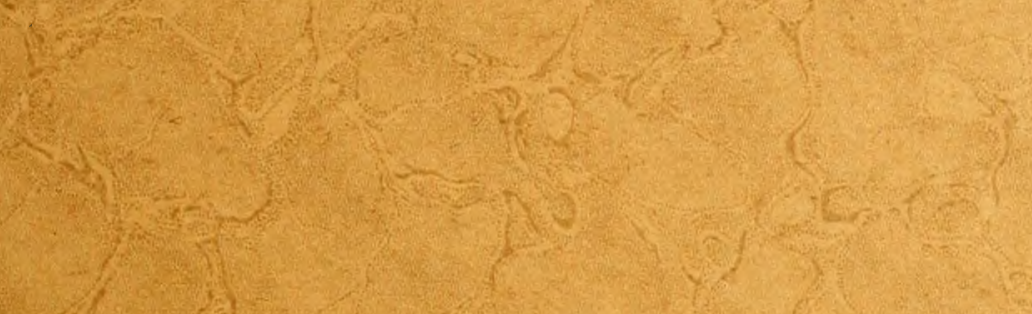

ati.

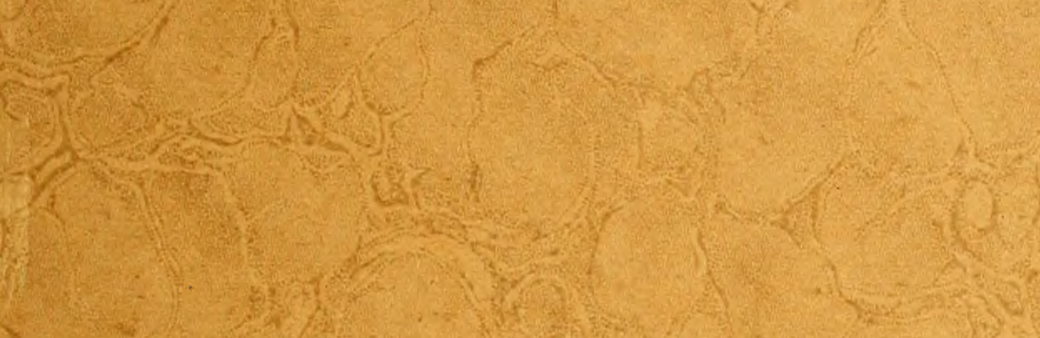

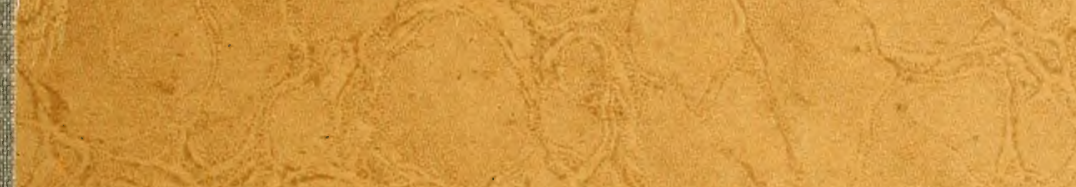

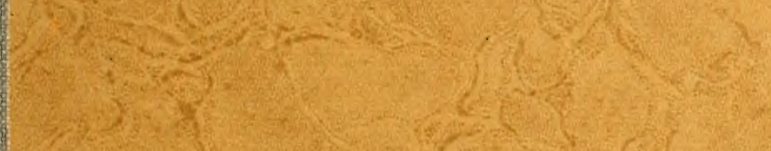

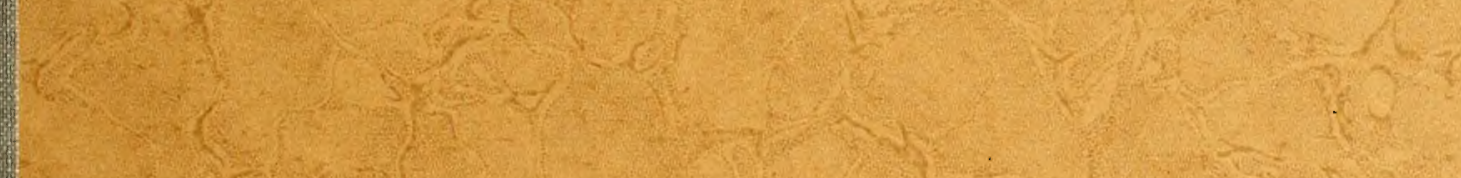

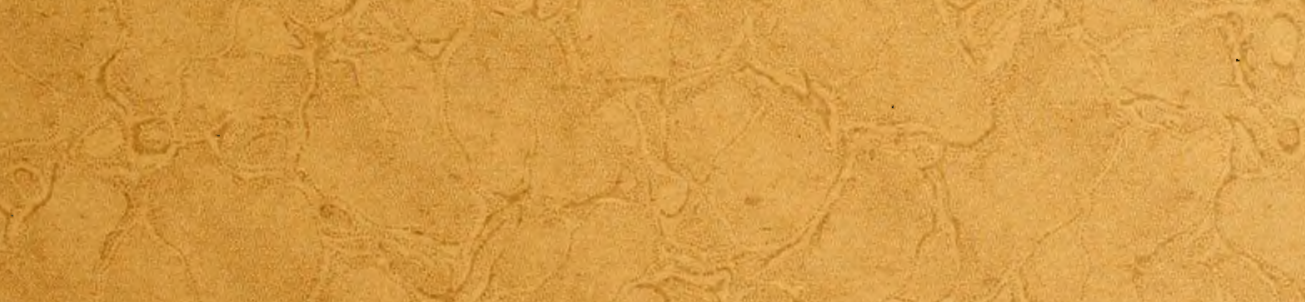

I.

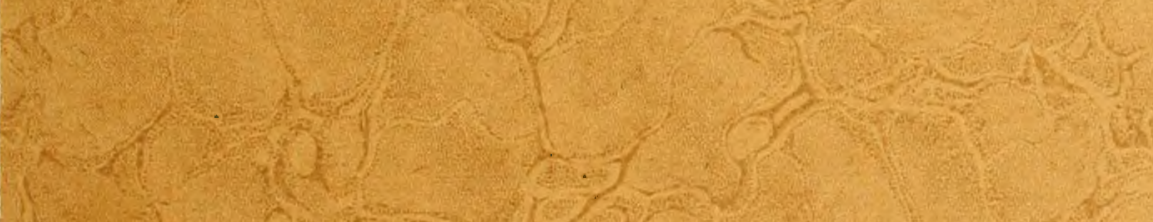

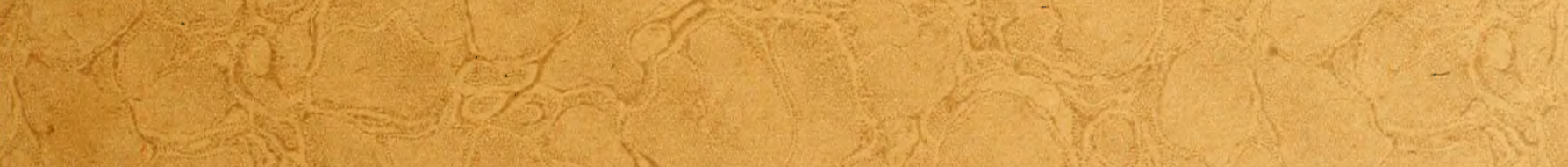

if

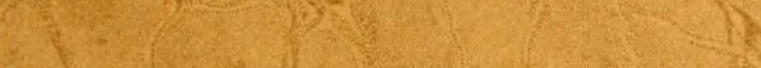

13

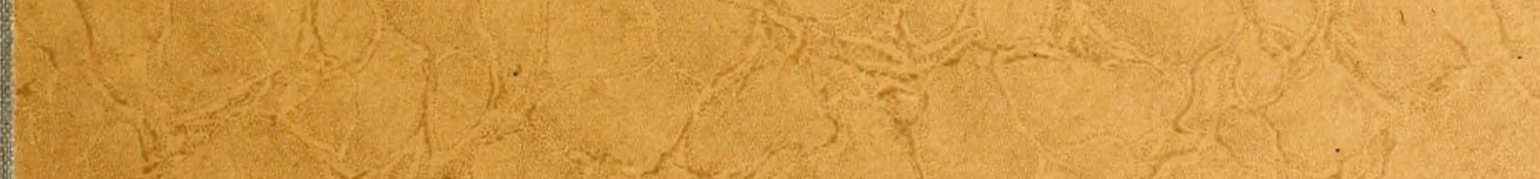




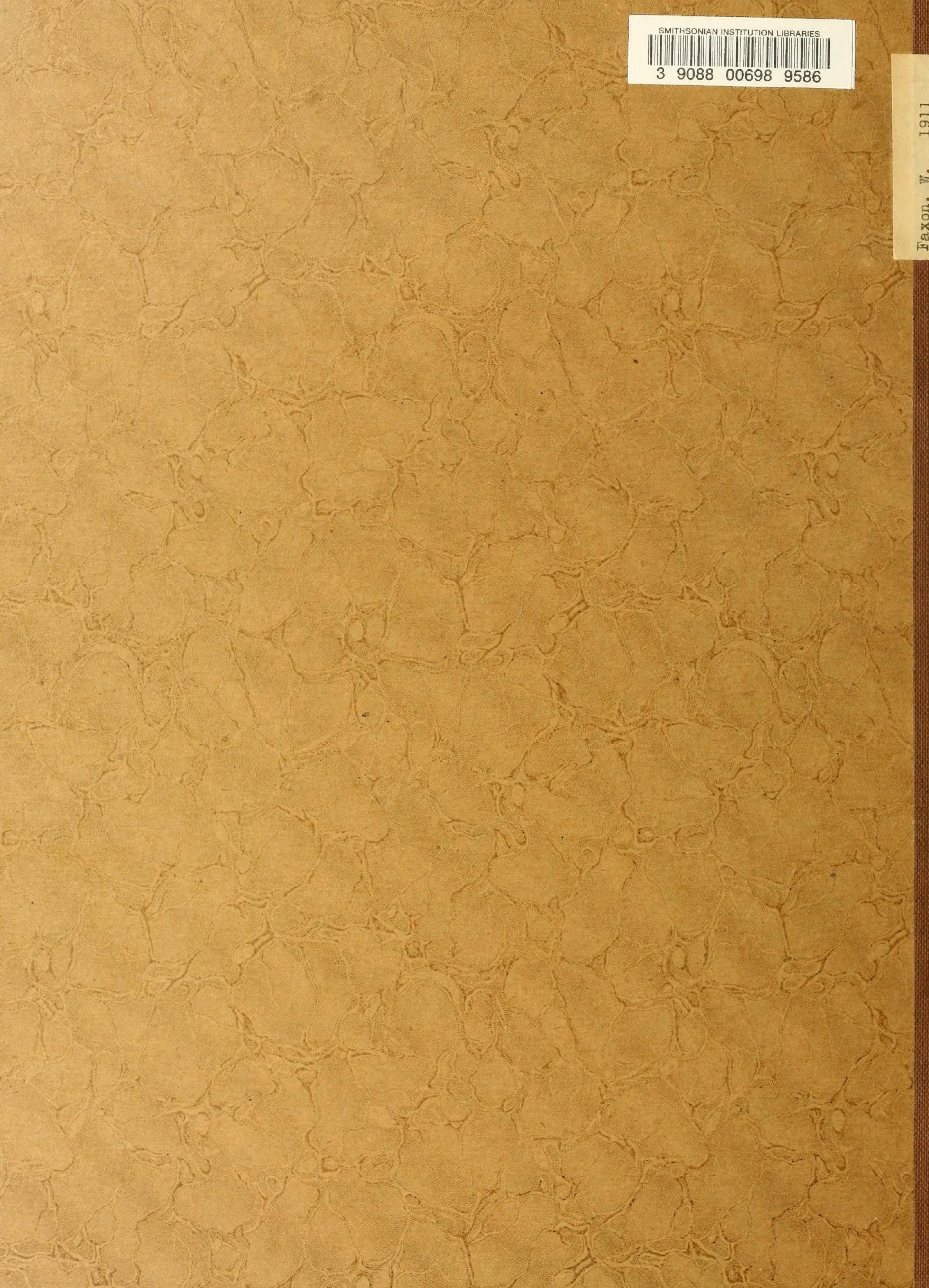

